\title{
Hyperlipemia and Oxidation of LDL Induce Vascular Smooth Muscle Cell Growth: An Effect Mediated by the HLH Factor Id3
}

\author{
Angela M. Taylor ${ }^{a}$ Feng Li $^{a}$ Pushpa Thimmalapura ${ }^{a}$ Ross G. Gerrity \\ lan J. Sarembock ${ }^{\text {a }}$ Scott Forrest $^{a}$ Sarah Rutherford $^{\mathrm{a}}$ \\ Coleen A. McNamara ${ }^{a}$ \\ a Department of Internal Medicine, Cardiovascular Division, and the Cardiovascular Research Center, \\ University of Virginia Health System, Charlottesville, Va.; ' ${ }^{b}$ Department of Pathology, Medical College of Georgia, \\ Augusta, Ga., USA
}

\section{Key Words}

Hypercholesterolemia · Muscle, smooth •

Atherosclerosis · Oxidized LDL · Transcription factors

\begin{abstract}
Hyperlipemia and oxidized LDL (ox-LDL) are important independent cardiovascular risk factors. Ox-LDL has been shown to stimulate vascular smooth muscle cell (VSMC) proliferation. However, the effects of hyperlipemia and the molecular mechanisms mediating hyperlipemia and ox-LDL effects on VSMC growth are poorly understood. The helix-loop-helix (HLH) transcription factor, Id3, is a redox-sensitive gene expressed in VSMC in response to mitogen stimulation and vascular injury. Accordingly, we hypothesize that Id3 is an important mediator of ox-LDL and hyperlipemia-induced VSMC growth. Aortas harvested from hyperlipemic pigs demonstrated significantly more Id3 than normolipemic controls. Primary VSMC were stimulated with ox-LDL, native LDL, sera from hyperlipemic pigs, or normolipemic pigs. VSMC exposed to hyperlipemic sera demonstrated in-
\end{abstract}

creased Id3 expression, VSMC growth and S-phase entry and decreased $\mathrm{p} 21^{\mathrm{cip} 1}$ expression and transcription. Cells stimulated with ox-LDL demonstrated similar findings of increased growth and Id3 expression and decreased p2 $1^{\text {cip } 1}$ expression. Moreover, the effects of ox-LDL on growth were abolished in cells devoid of the Id3 gene. Results provide evidence that the HLH factor Id3 mediates the mitogenic effect of hyperlipemic sera and oxLDL in VSMC via inhibition of $\mathrm{p} 21^{\text {cip } 1}$ expression, subsequently increasing DNA synthesis and proliferation.

Copyright (C) 2006 S. Karger AG, Basel

\section{Introduction}

Hyperlipemia has been established as an independent risk factor for the development of atherosclerotic cardiovascular disease $[1,2]$. It has been demonstrated that in the presence of elevated lipid levels, the earliest event in the development of the atherosclerotic lesion is the transport into and retention of low-density lipoprotein (LDL) in the artery wall $[3,4]$. LDL then undergoes oxidation

\section{KARGER}

(c) 2006 S. Karger AG, Basel

Fax +41613061234 E-Mail karger@karger.ch www.karger.com
Dr. Coleen A. McNamara

University of Virginia Health System

Cardiovascular Division, PO Box 801394

Charlottesville, VA 22908 (USA)

Tel. +1 434982 3366, Fax +1 434243 6280, E-Mail cam8c@virginia.edu 
and is taken up by macrophages with the subsequent formation of foam cells and accumulation of oxidized lipid in the artery wall $[3,4]$. The presence of smooth muscle cells, abundance of intercellular matrix, and greater accumulation of macrophages and lipoprotein distinguishes progression-prone from progression-resistant lesions [4]. In fact, progression-resistant lesions contain few vascular smooth muscle cells (VSMC) [4]. However, the exact role of VSMC in this disease process is still unclear. It is believed that enhanced VSMC migration and proliferation contribute to early lesion development as does secretion of proinflammatory cytokines by VSMC. In hypercholesterolemic animals, VSMC in developing lesions show increased proliferation. In contrast, late in lesion development, matrix secretion by VSMC appears to increase plaque stability [5-7]. Thus, a further understanding of the role of VSMC in the early development of lesions, particularly in response to hyperlipemia, is of key importance to understanding the progression of vascular diseases. While much is known about the effects of oxidized lipid on macrophages in the vessel wall, the molecular mechanisms that regulate the effects of hyperlipemia and oxidized lipids on vascular smooth muscle cell accumulation in developing lesions are poorly understood.

Oxidized LDL (ox-LDL) has been shown to affect VSMC growth-inducing proliferation or apoptosis depending on the concentration and level of oxidation of the LDL [8-11]. Ox-LDL stimulates growth via an oxidative mechanism that causes the release of FGF-2, potentiates the mitogenic effect of angiotensin II, and stimulates MAPK activation [12-14]. In addition, ox-LDL has been shown to induce an increase in the expression of cell cycle regulatory proteins [15]. However, little is known about the effects of ox-LDL or hyperlipemia on nuclear factors that regulate the expression of cell cycle proteins.

The Id class of the helix-loop-helix (HLH) transcription factors has recently emerged as important regulators of cellular growth $[16,17]$. The original established paradigm for Id was an inhibitor of differentiation. Id dimerizes with ubiquitously expressed basic HLH (bHLH) factors such as the E2A proteins (E12 and E47) and inhibits their dimerization with cell-specific bHLH factors. DNA binding and subsequent activation of transcription is inhibited. In the absence of Id, E2A factors are free to dimerize and bind to DNA leading to activation of transcription and subsequently differentiation of the cell [18, 19]. This basic functional property of regulating gene expression through dimerization with functional DNAbinding proteins is also a mechanism whereby Id regu- lates cell cycle progression. bHLH factors such as E47 activate transcription of the cyclin-dependent kinase inhibitor $\mathrm{p} 21^{\text {cip } 1}[16,20]$. $\mathrm{p} 21^{\text {cip } 1}$ has been implicated as an important inhibitor of VSMC proliferation and vascular lesion formation $[21,22]$. Id3 has emerged as a redoxsensitive regulator of cell cycle gene expression and growth in VSMC and is expressed during vascular lesion formation in response to injury [23-25]. Thus it is appealing to hypothesize that hyperlipemia- and ox-LDL-induced VSMC growth is mediated by increased expression of Id 3 and inhibition of $\mathrm{p} 21^{\mathrm{cip} 1}$ transcription.

Results of the present study are the first to demonstrate, in vivo, that hyperlipemia leads to an increased expression of Id 3 in the vessel wall. Moreover, hyperlipemic sera from these same animals induce Id3 protein expression, growth, and enhanced S-phase entry in the VSMC. We, further, provide evidence that hyperlipemia increases Id 3 expression via induction of Id 3 transcription and induces a subsequent decrease in $\mathrm{p} 21^{\text {cip } 1}$ transcription. As ox-LDL is an important mediator of hyperlipemia, we provide evidence that cells stimulated with ox-LDL demonstrate increased VSMC growth and Id3 expression and decreased $\mathrm{p} 21^{\mathrm{cip} 1}$ expression. Moreover, the effects of ox-LDL on growth are abolished in cells devoid of the Id 3 gene, providing strong evidence for the necessity of Id 3 for ox-LDL-induced growth.

\section{Methods and Materials}

\section{Porcine Model}

Male Yorkshire pigs, 8-12 weeks old, were fed either a normal diet (final cholesterol levels of $65-105 \mathrm{mg} / \mathrm{dl}$ ) or a diet containing $1.5 \%$ cholesterol and $15 \%$ lard (final cholesterol levels of $287-$ $450 \mathrm{mg} / \mathrm{dl}$ ) for 20 weeks, sacrificed and sera and tissue harvested. All pigs used in this study were normoglycemic. As reported previously in the literature, hyperlipemic pigs develop atherosclerotic lesions in contrast to normolipemic pigs [26]. Levels of ox-LDL in this model increased linearly with total cholesterol levels (fig. 1).

\section{Serum Collection}

Whole blood was collected and allowed to coagulate. Samples were centrifuged for $10 \mathrm{~min}$ at $2,000 \mathrm{~g}$, serum removed, aliquotted and frozen at $-80^{\circ} \mathrm{C}$. Sera were normoglycemic and matched for glucose levels. Oxidation was determined using ELISA (Mercodia). Serum was kept under argon gas to prevent further oxidation.

\section{Protein Harvest}

Two-millimeter slices of abdominal aorta obtained from the same segment in each animal were snap-frozen in liquid nitrogen and smashed. Tissue was added to buffer ( $10 \mathrm{ml}$ of $25 \mathrm{~m} M$ HEPES, pH 7.5 and one complete mini EDTA-free protease inhibitor tablet; Roche), kept on ice, homogenized and centrifuged at 5,000 $\mathrm{g}$ for $15 \mathrm{~min}$ at $4^{\circ} \mathrm{C}$. Supernatant was collected. 


\section{Measurement of Oxidation}

Levels of oxidation were determined by ox-LDL ELISA (Mercodia) which is a solid two-site enzyme immunoassay based on a direct sandwich technique in which two antibodies are directed against separate epitopes of the ox-LDL apo B molecule.

\section{Cell Culture}

Primary aortic VSMC were isolated from Id3 knockout mice (kindly provided by Yuan Zhuang), Id3 wild-type mice (littermate controls) and Yorkshire pigs and grown in Dulbeco's Modified Eagle Medium (DMEM F12) containing 10\% fetal bovine serum, $10 \mathrm{U} / \mathrm{ml}$ penicillin, and $10 \mu \mathrm{g} / \mathrm{ml}$ streptomycin. Cells were studied at passages $8-15$. Serum starvation consists of maintaining the cells in DMEM F12 with Pen/Strep devoid of serum for $48 \mathrm{~h}$. Stimulation with sera from the pig model was done following serum starvation and consisted of DMEM F12, Pen/Strep and 10\% serum from either normolipemic or hyperlipemic pigs.

\section{Analysis of Smooth Muscle Cell Proliferation}

Cells were harvested with trypsin and $100 \mu$ l of cells were added to $9.9 \mathrm{ml}$ of Isoton. Cell number was determined using the Beckman Coulter Counter according to the manufacturer's suggestions. Absolute cell number was counted in triplicate and averaged for each sample. Cell number was also determined using the CellTiter $96 \mathrm{AQ}_{\text {ueous }}$ One Solution Cell Proliferation Assay (Promega) according to the manufacturer's specifications.

\section{Cell Cycle Analysis}

Cells were fixed with ethanol, incubated with propidium iodide (PI) solution ( $10 \mathrm{ml}$ of $0.1 \%$ Triton X-100 (Sigma) in PBS, $2 \mathrm{mg}$ DNase-free RNase A (Sigma), and $200 \mu \mathrm{l}$ of $1 \mathrm{mg} / \mathrm{ml} \mathrm{PI;} \mathrm{Sigma)}$ for $15 \mathrm{~min}$ at $36^{\circ} \mathrm{C}$ and cell cycle analysis was performed using the Becton Dickinson FACS Calibur dual laser benchtop cytometer and ModFitLT version 3 software.

\section{Lipoprotein Preparation}

Human native LDL (n-LDL) and ox-LDL $\left(\mathrm{Cu}^{2+}\right.$ oxidation) were purchased from Intracel, dialyzed with Slide-A-Lyzer Dialysis Cassettes (Pierce) at room temperature for $2 \mathrm{~h}$ and then overnight at $4{ }^{\circ} \mathrm{C}$. Lipoproteins were stored at $4{ }^{\circ} \mathrm{C}$ under argon gas. Concentrations used are based on protein measurements.

\section{Western Blots}

Protein was electrophoresed on a 15\% SDS-polyacrylamide gel, transferred to a PVDF membrane and blocked for $1 \mathrm{~h}$ at room temperature in 5\% nonfat milk in PBS-Tween (PBST). The membrane was incubated with rabbit polyclonal Id3 (Santa Cruz Biotechnology) or mouse monoclonal p2 $1^{\text {cip } 1}$ (Pharmingen) antibodies overnight at $4^{\circ} \mathrm{C}$, washed and incubated in secondary antibody (horseradish-peroxidase-conjugated) diluted 1:5,000 in PBST for $1 \mathrm{~h}$ at room temperature. Immunoreactive bands were visualized by chemiluminescence after incubation with ECL reagent (Amersham Pharmacia Biotech). The blots were stripped and reprobed with an anti-tubulin antibody to control for protein loading.

\section{Promoter-Reporter Analysis}

Porcine primary aortic VSMC were transfected with $0.5 \mu \mathrm{g}$ pK7GFP and either $0.5 \mu \mathrm{g}$ p21Luc or pId3Luc. Luciferase activity was determined using a Luciferase Assay System (Promega). Samples were normalized for protein and transfection efficiency.

Id3 Regulates Hyperlipemia-Induced Smooth Muscle Cell Growth

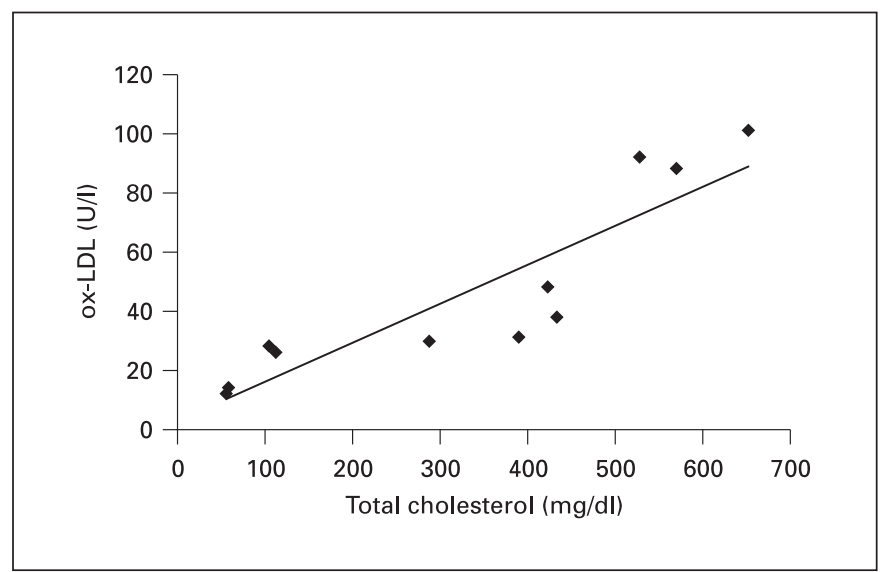

Fig. 1. ox-LDL increases linearly with total cholesterol. Levels of LDL oxidation were determined using a commercially available antibody assay. As total cholesterol increases in the porcine model, ox-LDL increases.

Viral Infection

VSMC were infected with 5 MOI of AdGFP or AdId3 and cell number measured at $24 \mathrm{~h}$.

Statistical Analysis

Differences between experimental values obtained were evaluated for statistical significance using a two-tailed Student's t test.

\section{Results}

\section{Effects of Hyperlipemia on Id3 Protein Levels in the Vessel Wall \\ We obtained sera and tissues from a hyperlipemic por-} cine model of spontaneous atherosclerosis that demonstrates vascular lesions similar to those found in human disease [26]. In order to determine if there are differences in Id 3 levels in the vessel wall in response to high-fat feeding in this model, protein was harvested and Western blots performed. Aortas from hyperlipemic animals sacrificed after 20 weeks of high-fat feeding contained more Id3 protein relative to normolipemic control aortas. Four animals were studied in each group $(\mathrm{p}<0.001)$ (fig. 2a, b).

\section{Effects of Hyperlipemia on Id3 Protein Expression, \\ Growth and S-Phase Entry in VSMC}

To determine if sera from these same animals induced Id 3 expression and growth in VSMC, cell number was assessed and Western blot analysis was performed on primary porcine aortic VSMC stimulated with hyperlipemic 
or normolipemic sera. Consistent with vessel wall data, cells stimulated with hyperlipemic sera demonstrated increased levels of Id3 protein compared with cells stimulated with normolipemic sera (fig. 3a). VSMC stimulated with hyperlipemic sera also grew significantly faster than cells exposed to normolipemic sera ( $p<0.01$ at $24 \mathrm{~h}, \mathrm{p}=$ 0.01 at 48 h) (fig. 3b). To determine the effects of hyperlipemic versus normolipemic sera on S-phase entry, cell cycle components were analyzed by FACS. VSMC stimulated with hyperlipemic sera had a significant increase in S-phase entry compared with cells stimulated with normolipemic sera ( $p=0.016)$ (fig. $3 c)$.

Fig. 2. Hyperlipemia induces Id 3 expression in the vessel wall. After 20 weeks of high-fat feeding, vessels were harvested and equal amounts of protein were analyzed for Id3. A representative Western blot is shown (a). Quantitative densitometry is shown from 4 animals from each group (b). Results are normalized to quantitative densitometry of the tubulin blot for each sample. Normolipemic animals had serum cholesterol levels of 65-105 mg/dl. Hyperlipemic animals had cholesterol levels of $287-450 \mathrm{mg} / \mathrm{dl}$. Hyperlipemic aortas demonstrated significantly more $\mathrm{Id} 3$ relative to normolipemic aortas $(* \mathrm{p}<0.001)$.

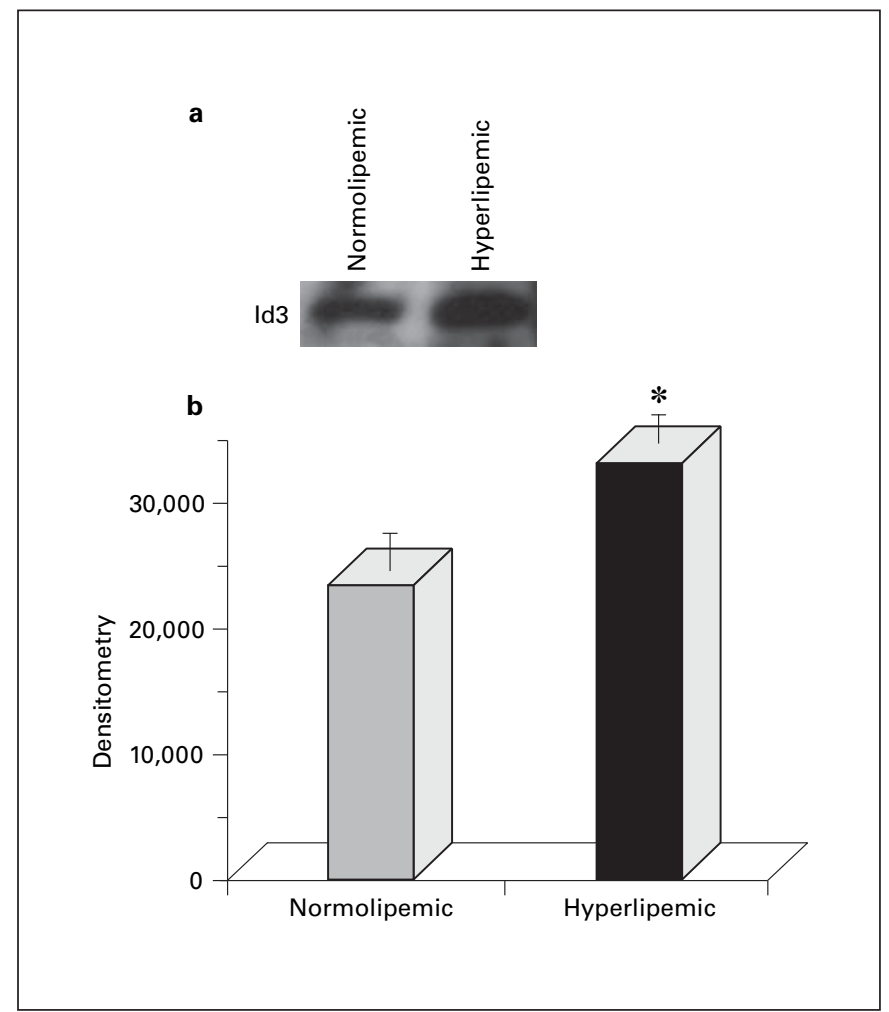

Fig. 3. Hyperlipemia increases Id 3 expression, VSMC growth, and S-phase entry. Porcine VSMC were plated in equal densities, quiesced for $48 \mathrm{~h}$ and stimulated with media containing either hyperlipemic or normolipemic sera. Normolipemic animals had serum cholesterol levels of 65-105 mg/ dl. Hyperlipemic animals had cholesterol levels of $287-450 \mathrm{mg} / \mathrm{dl}$. a Forty-eight hours after stimulation, equal amounts of protein were analyzed for Id 3 expression by Western blotting. The blot was stripped and reprobed with an anti-tubulin antibody to control for protein loading. b VSMC stimulated with hyperlipemic sera grew faster at all time points relative to normolipemic sera ( $* \mathrm{p}=0.008$ at $24 \mathrm{~h},{ }^{\dagger} \mathrm{p}=0.01$ at $48 \mathrm{~h}$ ). c Eighteen hours after stimulation, cells were stained with PI and analyzed for cell cycle components. VSMC stimulated with hyperlipemic sera had significantly greater S-phase entry relative to normolipemic sera $(* \mathrm{p}=0.016)$. Results are the average of three experiments performed in triplicate utilizing sera from 7 animals from each group.

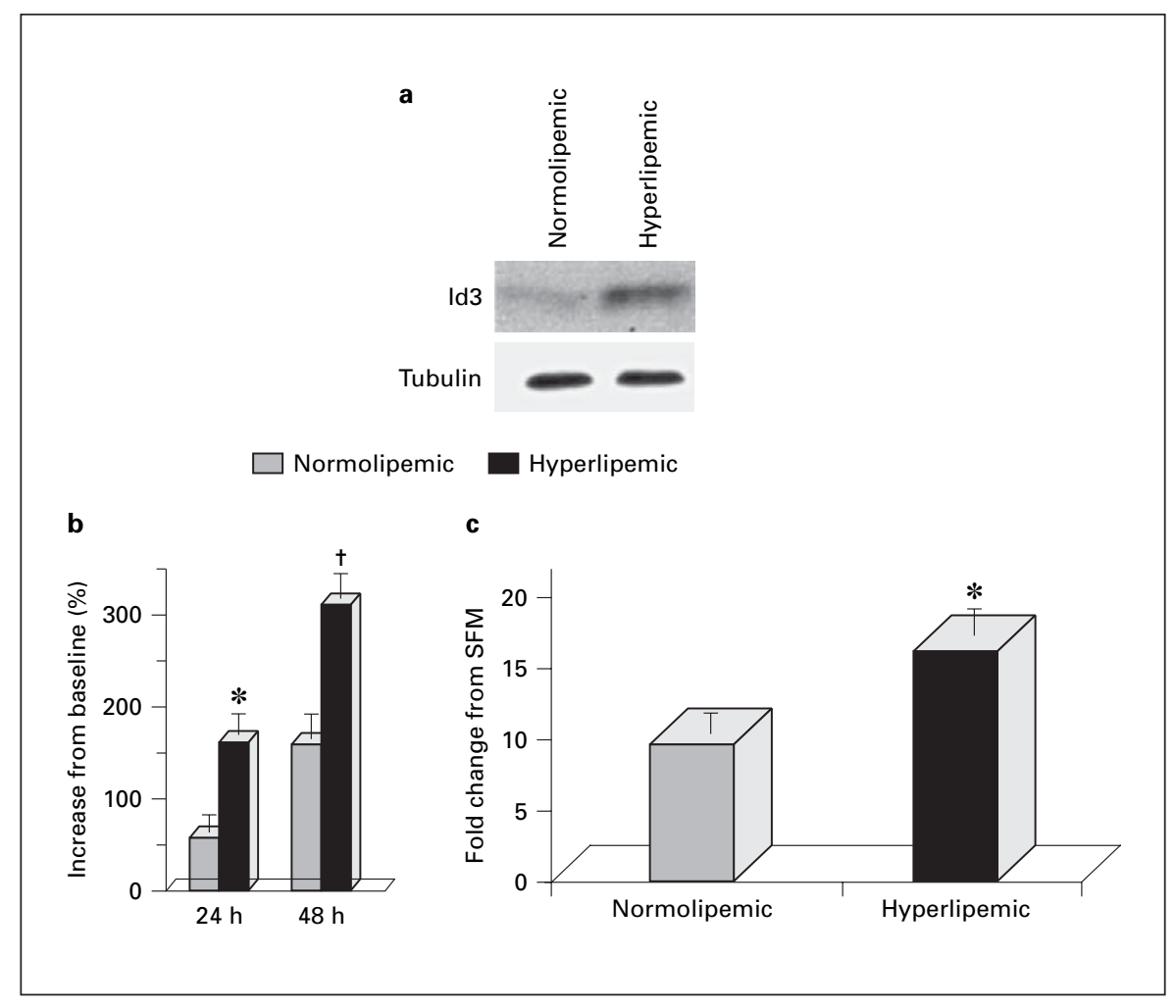


Fig. 4. Hyperlipemia increases Id 3 transcription and decreases p $21^{\text {cip } 1}$ transcription. Cells were cotransfected with pK7GFP and either pId3Luc or p21Luc. Cells were quiesced for $48 \mathrm{~h}$ and stimulated with either hyperlipemic or normolipemic sera. Luciferase activity was measured (normalized to protein concentration and GFP fluorescence) was measured 24 and 48 h later. a Hyperlipemic sera increased Id 3 promoter reporter activity relative to normolipemic sera (* p $<0.01$ at 24 and 48 h). b Hyperlipemic sera decreased $\mathrm{p} 21$ promoter reporter activity relative to normolipemic sera $\left(* p<0.01\right.$ at $24 \mathrm{~h},{ }^{\dagger} \mathrm{p}=0.02$ at $\left.48 \mathrm{~h}\right)$. Results are average of three experiments performed in triplicate utilizing sera from 7 animals from each group.

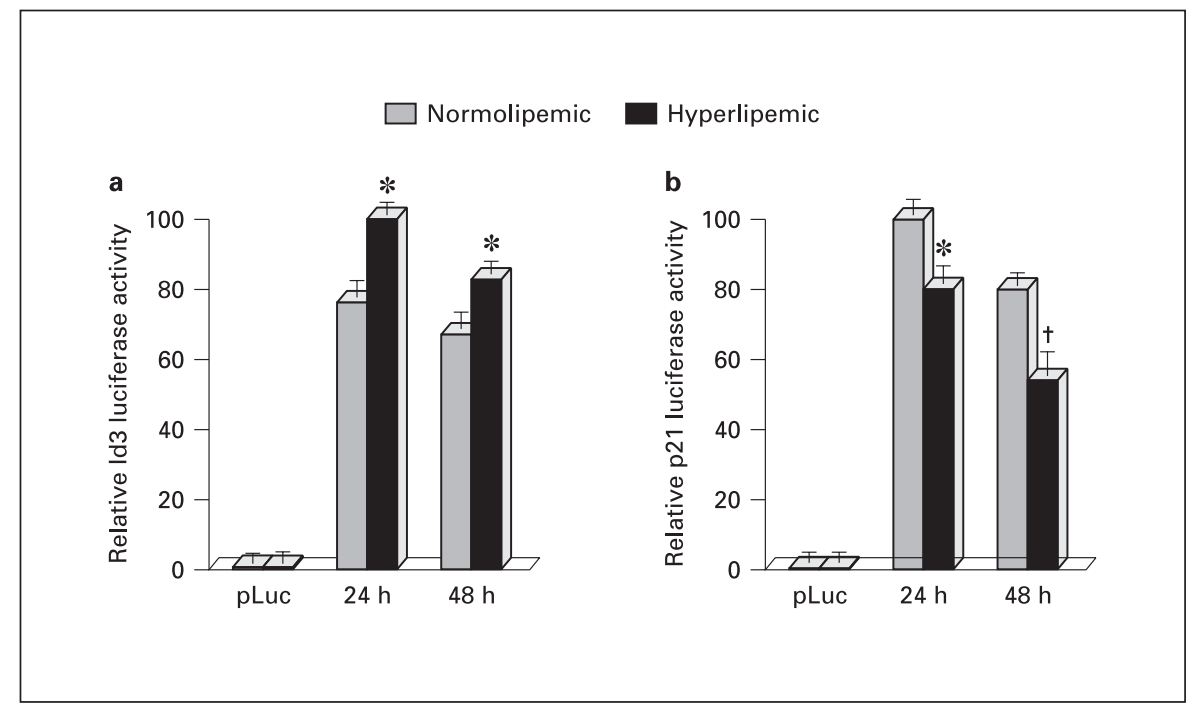

\section{Effects of Hyperlipemia on Id3 and p2 $1^{\text {cip } 1}$}

\section{Transcription}

To determine if the mechanism for hyperlipemia-induced Id 3 expression is at the level of transcription and if hyperlipemia-induced Id 3 expression results in downstream effects on the Id 3 target $\mathrm{p} 21^{\text {cip } 1}$, porcine VSMC were transfected with pK7GFP and either p21Luc or pId3Luc. The transfected cells were quiesced for $48 \mathrm{~h}$, then stimulated with either hyperlipemic or normolipemic sera. Indeed, hyperlipemic sera induced an increase in Id 3 promoter activity $(\mathrm{p}<0.01$ at 24 and $48 \mathrm{~h}$ ) (fig. $4 \mathrm{a})$. Consistent with known downstream effects of Id3, hyperlipemic sera also induced a subsequent decrease in $\mathrm{p} 21^{\mathrm{cip} 1}$ promoter activity ( $<<0.01$ at $24 \mathrm{~h}, \mathrm{p}=0.02$ at $48 \mathrm{~h}$ ) (fig. $4 b)$. Results were normalized for protein and GFP fluorescence.

\section{Effects of ox-LDL on VSMC Growth and Expression of Id 3 and $p 21^{\text {cip } 1}$}

To determine if growth-promoting concentrations of ox-LDL regulate $\mathrm{Id} 3$ and $\mathrm{p} 21^{\mathrm{cip} 1}$ expression, primary mouse aortic VSMC were stimulated with either $20 \mu \mathrm{g} /$

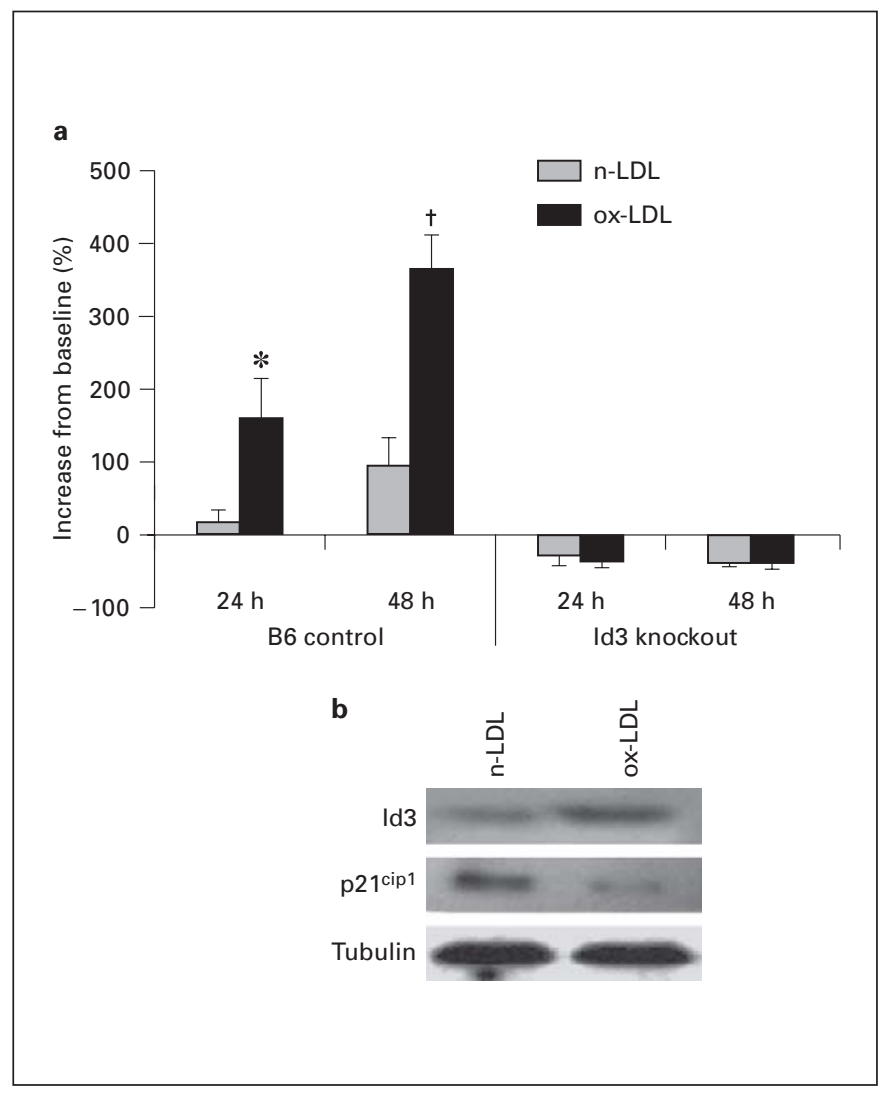

strated no increase in growth in response to ox-LDL. Results are averages of three experiments performed in triplicate. b At $48 \mathrm{~h}$, equal amounts of protein from control cell lysates were immunoblotted using antibodies to $\operatorname{Id} 3$ or $\mathrm{p} 21^{\text {cip } 1}$. The blot was stripped and reprobed with an anti-tubulin antibody to control for protein loading. 


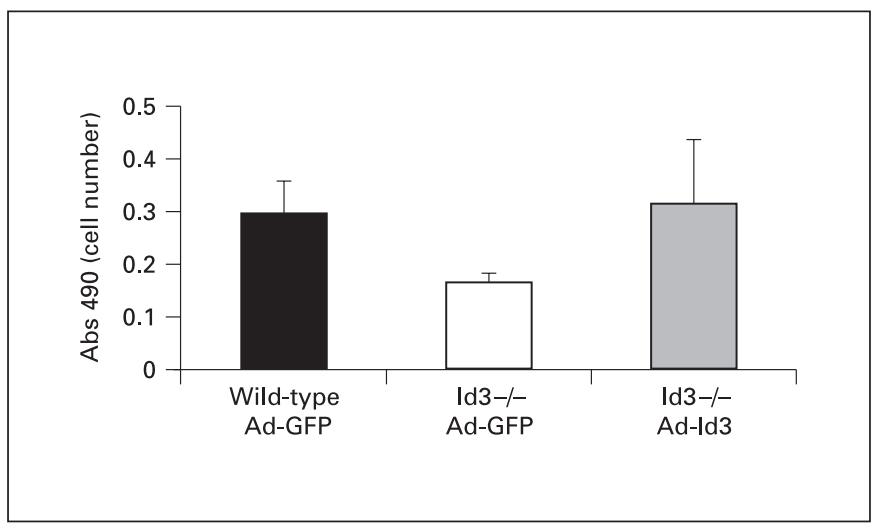

Fig. 6. AdId 3 infection rescues decreased proliferation of Id3-/cells. Wild-type and Id 3 knockout VSMC were infected with AdId3 or AdGFP control virus and assayed for cell number $24 \mathrm{~h}$ after infection. Control infected Id3 knockout cells demonstrated decreased proliferation relative to control infected wild type cells. Proliferation of Id 3 knockout cells is rescued with AdId3 infection.

$\mathrm{ml}$ of $\mathrm{n}-\mathrm{LDL}$ or $20 \mu \mathrm{g} / \mathrm{ml}$ of ox-LDL. Results demonstrated a significant increase in cell number in control VSMC treated with ox-LDL compared to those treated with $\mathrm{n}-\mathrm{LDL}$, confirming that ox-LDL is mitogenic to VSMC at this concentration ( $p<0.05$ at $24 \mathrm{~h}, \mathrm{p}<0.001$ at $48 \mathrm{~h}$ ). (fig. 5a). To determine if the growth-promoting effects of ox-LDL may be mediated through Id3, Western blot analysis was performed on lysates from parallel plates. Relative to n-LDL, ox-LDL treated cells had increased $\mathrm{Id} 3$ and decreased $\mathrm{p} 21^{\text {cip } 1}$ protein expression (fig. 5b).

\section{Id3 Is Critical to ox-LDL-Induced Growth}

To determine if Id 3 is necessary for ox-LDL-induced VSMC growth, control and Id 3 knockout primary aortic VSMC were stimulated with $20 \mu \mathrm{g} / \mathrm{ml}$ of ox-LDL or nLDL. Interestingly, in contrast to wild-type cells, Id3 knockout cells demonstrated no growth in response to stimulation. This finding provides strong evidence that Id 3 is critical for VSMC growth ( $<<0.05$ at $24 \mathrm{~h}, \mathrm{p}<$ 0.001 at $48 \mathrm{~h}$ ) (fig. 5a). Rescue experiments performed by infecting Id3 knockout VSMC with an adenovirus expressing Id 3 resulted in return of normal growth, confirming that the growth defect in Id 3 knockout cells is due to loss of Id3 (fig. 6).

\section{Discussion}

Previous studies have shown an increase in Id 3 expression in response to mechanical injury $[23,25]$; however, the results of the present study offer the first in vivo evidence demonstrating increased expression of Id 3 in the vessel wall of hyperlipemic animals. Interestingly, they suggest that this effect is mediated by a circulating factor as sera from these same animals induces an increase in Id 3 expression and growth in cultured VSMC. The precise factors responsible for increasing Id 3 expression in response to hyperlipemia are unknown. The effects of hyperlipemia are thought to be mediated through elevated levels of oxidative stress [27]. Indeed, increased plasma levels of ox-LDL have been demonstrated in patients with atherosclerotic lesions and it has been suggested that the ox-LDL/total cholesterol ratio is an indicator for the increased risk of vascular events [28]. Further, as serum levels of LDL increase, serum levels of ox-LDL increase [28]. Data from this study demonstrate this correlation to be present in this porcine model as well. While other circulating factors may play a role, data from this study suggest that the circulating factor in hyperlipemic sera that induces Id 3 expression and VSMC growth is oxLDL. Similar to hyperlipemic sera, ox-LDL induces VSMC growth along with an increase in Id 3 and a decrease in $\mathrm{p} 21^{\text {cip } 1}$ expression.

Oxidation of LDL has emerged as the initiating event in lesion formation [3, 4]. The effects of ox-LDL on signaling pathways and transcription factors that lead to macrophage accumulation and inflammatory responses in the vessel wall are well known [27]. However, while much is known about the signaling molecules induced by ox-LDL in VSMC [12-14], little is known about the effects on transcription factors which regulate VSMC proliferation during vascular lesion development. In the present study, we provide the first evidence that ox-LDL increases the expression of Id3. Previous studies have shown that delivery of Id3 antisense to VSMC inhibited the increases in DNA synthesis induced by angiotensin II and xanthine/xanthine oxidase (X/XO), suggesting that levels of Id 3 are important determinants of mitogen and ROS-induced G1-S progression [24]. Moreover, increased Id 3 expression resulted in a decrease in $\mathrm{p} 21^{\mathrm{cip} 1}$ transcription and an increase in DNA synthesis and VSMC number [29]. While Id3 is not specific to the ox-LDL pathway, results of the present study demonstrating ox-LDL induction of Id3 expression and loss of ox-LDL-induced mitogenesis in Id3 knockout VSMC provide evidence that Id 3 is a critical component of ox-LDL-induced growth signaling in VSMC. 
Ox-LDL regulates the expression of genes associated with atherosclerosis, including the redox-sensitive transcription factors activator protein-1 (AP-1) and NF-кB, MAPK, and the vascular gene expression of ICAM-1 and VCAM-1 [27, 30-34]. Interestingly, the Id3 promoter contains a binding site for AP- 1 providing a potential mechanism whereby ox-LDL may induce Id 3 transcription [35]. Whether hyperlipemia regulates Id 3 transcription via these factors is unknown. Further study to identify the cis- and trans-acting factors regulating hyperlipemia-induced Id3 expression may provide important insight into the molecular mechanisms that regulate the effects of hyperlipemia and oxidation on VSMC growth and atherosclerotic lesion progression.

\section{Acknowledgements}

This work was supported by the Whitaker Special Opportunity Award 'Genetic Engineering Targeting Vascular Disease' and an AHA fellowship award, Virginia Affiliate (FL); NIH RO1 HL62522 (CAM) and P01 HL.55798 (RGG,CAM); NIH training grant T32 HL-07355 (AMT). We thank Yuan Zhuang for kindly providing us with Id3 knockout mice.

\section{References}

1 Cui Y, Blumenthal RS, Flaws JA, Whiteman MK, Langenberg P, Bachorik PS, Bush TL: Non-high-density lipoprotein cholesterol level as a predictor of cardiovascular disease mortality. Arch Internal Med 2001;161:1413-1419.

-2 Heart Protection Study Collaborative Group: MRC/BHF Heart Protection Study of cholesterol lowering with simvastatin in 20,536 highrisk individuals: a randomised placebo-controlled trial. Lancet 2002;360:7-22.

-3 Navab M, Berliner JA, Watson AD, Hama SY, Territo MC, Lusis AJ, Shih DM, Van Lenten BJ, Frank JS, Demer LL, Edwards PA, Fogelman AM: The Yin and Yang of oxidation in the development of the fatty streak. A review based on the 1994 George Lyman Duff Memorial Lecture. Arterioscler Thromb Vasc Biol 1996;16:831-842.

-4 Stary HC, Chandler AB, Glagov S, Guyton JR, Insull W Jr, Rosenfeld ME, Schaffer SA, Schwartz CJ, Wagner WD, Wissler RW: A definition of initial, fatty streak, and intermediate lesions of atherosclerosis. A report from the Committee on Vascular Lesions of the Council on Arteriosclerosis, American Heart Association. Circulation 1994;89:2462-2478.

-5 Lafont A, Libby P: The smooth muscle cell: sinner or saint in restenosis and the acute coronary syndromes? J Am Coll Cardiol 1998;32: 283-285.

6 Lusis AJ: Atherosclerosis. Nature 2000;407: 233-241.

7 Braganza DM, Bennett MR: New insights into atherosclerotic plaque rupture. Postgrad Med J 2001;77:94-98

-8 Han CY, Pak YK: Oxidation-dependent effects of oxidized LDL: proliferation or cell death. Exp Mol Med 1999;31:165-173.

-9 Bjorkerud B, Bjorkerud S: Contrary effects of lightly and strongly oxidized LDL with potent promotion of growth versus apoptosis on arterial smooth muscle cells, macrophages, and fibroblasts. Arterioscler Thromb Vasc Biol 1996; 16:416-424.
10 Auge N, Pieraggi MT, Thiers JC, Negre-Salvayre A, Salvayre R: Proliferative and cytotoxic effects of mildly oxidized low-density lipoproteins on vascular smooth-muscle cells. Biochem J 1995;309:1015-1020.

11 Chatterjee S: Role of oxidized human plasma low density lipoproteins in atherosclerosis: effects on smooth muscle cell proliferation. Mol Cell Biochem 1992;111:143-147.

12 Chai YC, Howe PH, DiCorleto PE, Chisolm GM: Oxidized low density lipoprotein and lysophosphatidylcholine stimulate cell cycle entry in vascular smooth muscle cells. Evidence for release of fibroblast growth factor-2. J Biol Chem 1996;271:17791-17797.

13 Watanabe T, Pakala R, Katagiri T, Benedict CR: Mildly oxidized low-density lipoprotein acts synergistically with angiotensin II in inducing vascular smooth muscle cell proliferation. J Hypertens 2001;19:1065-1073.

14 Kusuhara M, Chait A, Cader A, Berk BC: Oxidized LDL stimulates mitogen-activated protein kinases in smooth muscle cells and macrophages. Arterioscler Thromb Vasc Biol 1997; 17:141-148.

15 Zettler ME, Prociuk MA, Austria JA, Massaeli H, Zhong G, Pierce GN: OxLDL stimulates cell proliferation through a general induction of cell cycle proteins. Am J Physiol 2003;284: H644-H653.

16 Prabhu S, Ignatova A, Park ST, Sun XH: Regulation of the expression of cyclin-dependent kinase inhibitor $\mathrm{p} 21$ by E2A and Id proteins. Mol Cell Biol 1997; 17:5888-5896.

17 Peverali FA, Ramqvist T, Saffrich R, Pepperkok R, Barone MV, Philipson L: Regulation of G1 progression by E2A and Id helix-loophelix proteins. EMBO J 1994;13:4291-4301.

18 Olson EN: MyoD family: a paradigm for development? Genes Dev 1990;4:1454-1461.
19 Lassar AB, Davis RL, Wright WE, Kadesch T, Murre C, Voronova A, Baltimore D, Weintraub H: Functional activity of myogenic HLH proteins requires hetero-oligomerization with E12/E47-like proteins in vivo. Cell 1991;66: 305-315.

20 Halevy O, Novitch BG, Spicer DB, Skapek SX, Rhee J, Hannon GJ, Beach D, Lassar AB: Correlation of terminal cell cycle arrest of skeletal muscle with induction of $\mathrm{p} 21$ by MyoD. Science 1995;267:1018-1021.

- 21 Tanner FC, Yang ZY, Duckers E, Gordon D, Nabel GJ, Nabel EG: Expression of cyclin-dependent kinase inhibitors in vascular disease. Circ Res 1998;82:396-403.

-22 Yang ZY, Simari RD, Perkins ND, San H, Gordon D, Nabel GJ, Nabel EG: Role of the p21 cyclin-dependent kinase inhibitor in limiting intimal cell proliferation in response to arterial injury. Proc Natl Acad Sci USA 1996;93: 7905-7910.

23 Matsumura ME, Li F, Berthoux L, Wei B, Lobe DR, Jeon C, Hammarskjold ML, McNamara CA: Vascular injury induces posttranscriptional regulation of the Id 3 gene: cloning of a novel Id 3 isoform expressed during vascular lesion formation in rat and human atherosclerosis. Arterioscler Thromb Vasc Biol 2001;21:752758.

24 Mueller C, Baudler S, Welzel H, Bohm M, Nickenig G: Identification of a novel redoxsensitive gene, Id 3 , which mediates angiotensin-II-induced cell growth. Circulation 2002; 105:2423-2428.

- 25 Nickenig G, Baudler S, Muller C, Werner C, Werner N, Welzel H, Strehlow K, Bohm M: Redox-sensitive vascular smooth muscle cell proliferation is mediated by GKLF and Id 3 in vitro and in vivo. FASEB J 2002;16:10771086.

-26 Gerrity RG, Natarajan R, Nadler JL, Kimsey T: Diabetes-induced accelerated atherosclerosis in swine. Diabetes 2001;50:1654-1665. 
27 Kunsch C, Medford RM: Oxidative stress as a regulator of gene expression in the vasculature. Circ Res 1999;85:753-766.

-28 Nordin FG, Hedblad B, Berglund G, Nilsson J: Plasma oxidized LDL: a predictor for acute myocardial infarction? J Int Med 2003;253: 425-429.

-29 Forrest ST, Barringhaus KG, Perlegas D, Hammarskjold ML, McNamara CA: Intron retention generates a novel Id3 isoform that inhibits vascular lesion formation. J Biol Chem 2004; 279:32897-32903.

30 Khan BV, Parthasarathy SS, Alexander RW, Medford RM: Modified low density lipoprotein and its constituents augment cytokine-activated vascular cell adhesion molecule-1 gene expression in human vascular endothelial cells. J Clin Invest 1995;95:1262-1270.
31 Ohlsson BG, Englund MC, Karlsson AL, Knutsen E, Erixon C, Skribeck H, Liu Y, Bondjers G, Wiklund O: Oxidized low density lipoprotein inhibits lipopolysaccharide-induced binding of nuclear factor-kappaB to DNA and the subsequent expression of tumor necrosis factor-alpha and interleukin-1beta in macrophages. J Clin Invest 1996;98:78-89.

32 Chatterjee S, Bhunia AK, Snowden A, Han H: Oxidized low density lipoproteins stimulate galactosyltransferase activity, ras activation, p44 mitogen activated protein kinase and c-fos expression in aortic smooth muscle cells. Glycobiology 1997; 7:703-710.
33 Rao GN, Alexander RW, Runge MS: Linoleic acid and its metabolites, hydroperoxyoctadecadienoic acids, stimulate c-Fos, c-Jun, and c-Myc mRNA expression, mitogen-activated protein kinase activation, and growth in rat aortic smooth muscle cells. J Clin Invest 1995; 96:842-847.

-34 Liao F, Andalibi A, deBeer FC, Fogelman AM, Lusis AJ: Genetic control of inflammatory gene induction and NF-kappa B-like transcription factor activation in response to an atherogenic diet in mice. J Clin Invest 1993;91:25722579.

35 Yeh K, Lim RW: Genomic organization and promoter analysis of the murine Id3 gene. Gene 2000;254:163-171. 